\title{
Pelvic inflammatory disease and contraception: a cross-sectional study in teritary center
}

\section{Pelvik inflamatuvar hastalık ve kontrasepsiyon: üçüncü basamak merkezde kesitsel bir çalışma}

\section{@Selçuk Kaplan, ĐPınar Kırıcı}

Adiyaman University School of Medicine, Department of Gynecology and Obstetrics, Adiyaman, Turkey

Cite this article as/Bu makaleye atıf için: Kaplan S, Kırıcı P. Pelvic inflammatory disease and contraception: a cross-sectional study in teritary center. J Health Sci Med 2020; 3(4): 454-459.

\begin{abstract}
Aim: To investigate the relationship between the contraceptive methods used in the patient population treated for pelvic inflammatory disease (PID) in a tertiary center with clinical and laboratory features and clinical outcome of PID.

Material and Method: This is a cross-sectional study using the anamnesis, examination findings, microbiological and pathological evaluation results of vaginal and cytological samples recorded in the hospital database of 974 patients treated with a diagnosis of PID in a tertiary center between 2017 and 2019.

Results: Copper-intrauterine device (Cu-IUD) was the most commonly used contraceptive method in women with a history of PID. When the cervicovaginal culture results are evaluated; E.coli positivity was more frequent in patients using CU-IUD and levonorgesterone IUD (LNG-IUD) ( $<0.001)$. The frequency of reproduction was higher in Group B Streptococcus $(<0.001)$ and other Streptococcus species $(=0.006)$ in those using condoms. While Staphylococcus $(=0.041)$ and Chlamydia trochomatis positivity was higher in combined oral contraceptives (COC) users, C. Trochomatis growth was frequent in depot medroxyprogeterone acetate (DMPA) users $(<0.001)$. Re-hospitalization was more common in the DMPA group compared to the other groups $(\mathrm{p}=0.008)$.

Conclusion: Contraceptive methods may affect the genital flora and may be a predisposing factor for the development of PID or prevent the development of PID.
\end{abstract}

Keywords: Contraceptive agents, intrauterine devices, long-acting reversible contraception, pelvic inflammatory disease

\section{ÖZ}

Amaç: Üçüncü basamak bir merkezde pelvik inflamatuvar hastalık (PID) için tedavi edilen hasta popülasyonunda kullanılan kontraseptif yöntemler ile PID’nin klinik ve laboratuvar özellikleri ve klinik sonuçları arasındaki ilişkiyi araştırmak.

Gereç ve Yöntem: Üçüncü basamak bir merkezde 2017-2019 yılları arasında PID tanısı ile tedavi edilen 974 hastanın hastane veri tabanına kaydedilen anamnez, muayene bulguları, vajinal ve sitolojik örneklerin mikrobiyolojik ve patolojik değerlendirme sonuçlarının kullanıldığı kesitsel bir çalışmadır.

Bulgular: Bakır-rahim içi araç (Cu-RİA), PID öyküsü olan kadınlarda en sık kullanılan kontraseptif yöntemdi. Servikovajinal kültür sonuçları değerlendirildiğinde; E.coli pozitifliği CU-RİA ve levonorgesteron RİA (LNG-RİA) kullanan hastalarda daha sıktı (<0.001). Prezervatif kullananlarda Grup B Streptococcus $(<0.001)$ ve diğer Streptococcus türlerinde $(=0.006)$ üreme sıklığı daha yüksekti. Staphylococcus $(=0.041)$ ve Chlamydia trochomatis pozitifliği kombine oral kontraseptif (COC) kullananlarda daha yüksek iken, C. Trochomatis büyümesi depo medroksiprogeteron asetat (DMPA) kullanıcılarında daha sık görülmüştür $(<0.001)$. Diğer gruplarla karşılaştırıldığında ( $\mathrm{p}=0.008)$.

Sonuç: Kontraseptif yöntemler genital florayı etkileyebilir ve PID gelişimi için predispozan bir faktör olabilir veya PID gelișimini önleyebilir.

Anahtar Kelimeler: Kontraseptif ajanlar, pelvik inflamatuvar hastalık, rahim içi araçlar, uzun etkili geri dönüşümlü kontrasepsiyon 


\section{INTRODUCTION}

Pelvic inflammatory disease (PID) is a serious complication of sexually transmitted infections and some gynecological procedures and is observed in 2-4\% of women of reproductive age $(1,2)$. PID is a term that includes upper genital tract infections such as endometritis, salpingitis, and oophoritis. It is caused by the spread of infections in the vagina and cervix to the uterine cavity (3). The diagnosis of PID should refer to the diagnostic criteria recommended by the Centers for Disease Control and Prevention (CDC), which consider abnormal vaginal discharge, fever, adnexal tenderness, cervicovaginal culture and laboratory data (1). Although PID is associated with sexually transmitted diseases, it can also be caused by endogenous infections of the vaginal flora. Risk factors for PID have been identified such as the use of an intrauterine device (IUD), curettage, multiple sexual partners, and sexually transmitted diseases (4), and barrier methods have been reported to be protective $(5,6)$. PID is an important cause of gynecological morbidity (7); adhesion secondary to tubal infection leads to tubal infertility, ectopic pregnancy and chronic pelvic pain (8-10).

Copper intrauterine device (Cu- IUD) is one of the most effective birth control methods and is frequently used in all age groups (11). There are studies reporting an increased risk of PID in women using Cu-IUD $(12,13)$. On the other hand, it has been reported that the risk of PID decreases in women who use levonorgesterone IUD (LNG-IUD) (14). It has been reported that the use of oral hormonal contraceptives reduces the risk of PID and the severity of inflammation decreases in these users (15). However, there is a lack of a current study that compares the effects of intrauterine, hormonal and barrier contraceptive methods on the clinical and outcomes of PID.

The purpose of our study in the light of this information; to investigate the relationship between the contraceptive methods used in the patient population treated for PID in a tertiary center with clinical and laboratory features and treatment outcome of PID.

\section{MATERIAL AND METHOD}

This is a cross-sectional study using the anamnesis, examination findings, and microbiological and pathological evaluation results of vaginal and cytological specimens recorded in our hospital database of patients admitted to our gynecology outpatient clinic in a tertiary center between January 2017 and December 2019. Ethics committee approval was received for this study from the Adiyaman University Non-interventional Clinical Researches Ethics Committee (No: 2020/6-23). This study was carried out in accordance with the Helsinki Declaration of Principles.
Among these patients, 1294 patients aged 18-45 years who had at least one minimum criteria and additional criteria were accepted as PID in accordance with the diagnostic criteria published in the latest guidelines by the United States Centers (1). In our center, patients who are diagnosed with severe disease, have nausea, vomiting and fever, have complications such as tuboovarian abscess, and those who do not comply with the outpatient regimen are hospitalized. Patients who were diagnosed with PID but had recently received outpatient oral antibiotic therapy, had a history of diabetes mellitus, had a history of minor or major surgery in the last 6 months, a history of immunosuppressive disease, or a history of immunosuppressive drug use in the last 6 months were excluded from the study. Based on these criteria, 974 female patients were included in the study. The patients were divided into the following groups according to the contraceptive method they used: copper IUD (Cu-IUD), combined oral contraceptive drug (COC), depot medroxyprogeterone acetate (DMPA), condom and LNG-IUD.

\section{Clinical and Laboratory Tests Reviewed}

Hospital entrance records taken from the electronic medical record database in our study center were made with service follow-up charts, laboratory results and discharge records.

Patient characteristics (age, parity, marital status, contraceptive method used, educational level) and PID clinical and laboratory characteristics (body temperature, C-reactive protein (CRP) serum level, white blood cell count (WBC), erythrocyte sedimentation rate (ESR) and physical examination findings (pelvic tenderness, fundal tenderness, cervical motion tenderness, abnormal cervical discharge) and cervicovaginal culture results) were noted. Cervicovaginal culture results; standard flora, Escherichia coli (E. coli), group B Streptococcus, Enterococcus faecalis (E. faecalis), Staphylococcus and its species, Streptococcus and species, Chlamydia trachomatis were noted for each group.

Clinical results such as hospitalization time and rehospitalization were noted. Body temperature measured at admission was recorded as measured in degrees Celsius centigrade. 38 and above was accepted as fever. Hospitalization was accepted as re-hospitalization within the first 30 days after discharge (16). Clindamycin/ gentamicin (900 mg IV clindamycin every eight hours plus a single daily dose (5 $\mathrm{mg} / \mathrm{kg})$ gentamicin) was administered, and after clinical improvement, the treatment regimen of oral clindamycin (450 mg orally four times daily) or doxycycline (100 mg twice daily) was administered. 


\section{Statistical Analysis}

SPSS 22 (IBM SPSS version 22, IBM Corp., Armonk, NY) program was used to analyze the data. Pearson's Chi-square test was used for significance between groups and Fisher's exact test was used for categorical variables. Student $t$ test and Mann-Whitney $U$ test were used for analysis of continuous variables. A two-sided $p$ value $<0.05$ showed statistical significance. A value of $\mathrm{p}<0.05$ was considered statistically significant.

\section{RESULTS}

The demographic characteristics of the groups are given in Table 1. Accordingly, $\mathrm{Cu}$-IUD was the most commonly used contraceptive method in women with a history of PID. Other preferred methods were COC, LNG-IUD, Condom and DMPA in order of frequency. The most preferred contraceptive method in the 18-25 age group was COC, the most preferred method in the 25-35 age group was $\mathrm{Cu}$-IUD and the most preferred method in the 35-45 age group was LNG-IUD.

In the analyzes made according to the PID clinical and laboratory results; Fever was more frequent in $\mathrm{Cu}$-IUD and DMPA groups (0.047). Pain and increased ESR, CRP, WBC values were common in those using COC and DMPA $(\mathrm{p}=<0.001)$. When the cervicovaginal culture results are evaluated; E.coli positivity was more frequent in patients using CU-IUD and LNG-IUD $(\mathrm{p}<0.001)$. The frequency of reproduction was higher in Group B
Streptococcus $(\mathrm{p}<0.001)$ and other Streptococcus species $(\mathrm{p}=0.006)$ in those using condoms. While Staphylococcus $(\mathrm{p}=0.041)$ and Chlamydia trochomatis positivity was higher in COC users, $C$. Trochomatis growth was frequent in DMPA users $(\mathrm{p}<0.001)$ (Table 2).

When hospitalization times of the patients were compared according to the groups, there was no significant difference $(p>0.05)$. However, re-hospitalization was more common in the DMPA group compared to the other groups $(\mathrm{p}=0.008)$ (Table 2).

\section{DISCUSSION}

PID occurs with ascending spread of cervical infections. N. Gonorrhoeae, C. Trochomatis and anaerobic and facultative bacteria found in the vaginal flora were isolated in the fallopian tubes of women with acute PID (17). PID is affected by many mechanisms such as reduction in normal vaginal lactobacilli, development of bacterial vaginosis, reproduction of anaerobic microflora. The presence of bacterial vaginosis may affect the cervical barrier and cause the progression of microorganisms in the upper genital tract $(18,19)$. It has been shown in various previous publications that the risk of PID increases with the use of IUD $(20,21)$. In a recent study conducted in a large group of patients in Turkey bacterial colonization increases with use $\mathrm{Cu}$-IUD, but the frequency of the PID has not been shown to increase with the IUD (22).

\begin{tabular}{|c|c|c|c|c|c|}
\hline & Cu-IUD n=412 & $\operatorname{COC} n=239$ & DMPA $n=43$ & Condom $n=117$ & LNG-IUD $n=163$ \\
\hline \multicolumn{6}{|l|}{ Age } \\
\hline $18-25$ & $55(13.4 \%)$ & $151(63.1 \%)$ & $19(44.2 \%)$ & $47(40.2 \%)$ & $28(17.2 \%)$ \\
\hline $25-35$ & $263(63.8 \%)$ & $74(31 \%)$ & $15(34.9 \%)$ & $14(12 \%)$ & $31(19 \%)$ \\
\hline $35-45$ & $94(22.8 \%)$ & $14(5.9 \%)$ & $9(20.9 \%)$ & $56(47.8 \%)$ & $104(63.8 \%)$ \\
\hline \multicolumn{6}{|l|}{ Marial Status } \\
\hline Married & $354(85.9 \%)$ & $164(68.6 \%)$ & $9(20.9 \%)$ & $63(53.9 \%)$ & $146(89.6 \%)$ \\
\hline Divorced & $58(14.1 \%)$ & $75(31.4 \%)$ & $34(79.1 \%)$ & $35(29.9 \%)$ & $17(10.4 \%)$ \\
\hline Single & - & - & - & $19(16.2 \%)$ & - \\
\hline \multicolumn{6}{|l|}{ Obstetric History } \\
\hline Gravida & $3.19 \pm 1.90$ & $2.34 \pm 2.00$ & $3.66 \pm 1.91$ & $2.12 \pm 1.81$ & $2.07 \pm 2.00$ \\
\hline Parity & $2.56 \pm 1.54$ & $1.67 \pm 1.35$ & $2.88 \pm 1.42$ & $1.87 \pm 1.23$ & $1.74 \pm 1.09$ \\
\hline Abortus & $0.62 \pm 0.71$ & $0.67 \pm 0.91$ & $0.83 \pm 1.23$ & $0.62 \pm 0.71$ & $0.63 \pm 0.89$ \\
\hline \multicolumn{6}{|l|}{ Educational Level } \\
\hline Middle school and pre-school & $151(36.6 \%)$ & $17(7.1 \%)$ & $4(9.3 \%)$ & $33(28.2 \%)$ & $86(52.8 \%)$ \\
\hline High school & $138(33.5 \%)$ & $93(38.9 \%)$ & $9(20.9 \%)$ & $39(33.3 \%)$ & $29(17.8 \%)$ \\
\hline License & $74(18 \%)$ & $81(33.9 \%)$ & $19(44.2 \%)$ & $17(14.5 \%)$ & $21(12.9 \%)$ \\
\hline Graduate & $49(11.9 \%)$ & $48(20.1 \%)$ & $11(25.6 \%)$ & $28(23.9 \%)$ & $27(16.5 \%)$ \\
\hline \multicolumn{6}{|l|}{ Body Mass Index } \\
\hline$<25$ & $69(16.7 \%)$ & $19(7.9 \%)$ & $21(48.8 \%)$ & $61(52.1 \%)$ & $47(28.8 \%)$ \\
\hline $25-29.99$ & $294(73.4 \%)$ & $173(72.4 \%)$ & $19(44.3 \%)$ & $35(29.9 \%)$ & $83(51 \%)$ \\
\hline$>30$ & $49(11.9 \%)$ & $47(19.7 \%)$ & $3(6.9 \%)$ & $21(18 \%)$ & $33(20.2 \%)$ \\
\hline
\end{tabular}




\begin{tabular}{|c|c|c|c|c|c|c|}
\hline & $\begin{array}{c}\text { IUD } \\
\mathrm{n}=412\end{array}$ & $\begin{array}{c}\text { COC } \\
n=239\end{array}$ & $\begin{array}{c}\text { DMPA } \\
n=43\end{array}$ & $\begin{array}{c}\text { Condom } \\
\mathrm{n}=117\end{array}$ & $\begin{array}{c}\text { LNG-IUD } \\
n=163\end{array}$ & $\mathbf{p}$ \\
\hline \multicolumn{7}{|l|}{ Clinicsl Features } \\
\hline Fever $(>38)$ & $324(78.6 \%)$ & $207(86.6 \%)$ & $40(93 \%)$ & $63(53.9 \%)$ & $51(31.3 \%)$ & 0.047 \\
\hline Pain (lower abdominal. fundal. cervikal motion) & $247(59.9 \%)$ & $224(93.7 \%)$ & $37(86 \%)$ & $71(60.7 \%)$ & $84(51.5 \%)$ & $<0.001$ \\
\hline Laboratory value (WBC. CRP ve ESR\%) & $379(92 \%)$ & $171(71.5 \%)$ & $43(100 \%)$ & $98(83.8 \%)$ & $102(62.6 \%)$ & $<0.001$ \\
\hline \multicolumn{7}{|l|}{ Cervicovaginal Culture } \\
\hline Escherichia coli & $73(17.8 \%)$ & $9(3.8 \%)$ & $5(11.7 \%)$ & $13(11.1 \%)$ & $41(25.2 \%)$ & $<0.001$ \\
\hline Group B Streptococcus & $53(12.9 \%)$ & $29(12.1 \%)$ & $6(14 \%)$ & $24(20.5 \%)$ & $21(12.8 \%)$ & $<0.001$ \\
\hline Enterococcus faecalis & $28(6.8 \%)$ & $7(2.9 \%)$ & $1(2.3 \%)$ & $12(10.3 \%)$ & $19(11.7 \%)$ & 0.51 \\
\hline Staphylococcus spp. & $17(4.1 \%)$ & $26(10.9 \%)$ & - & $3(2.6 \%)$ & $9(5.5 \%)$ & 0.041 \\
\hline Streptococcus spp. & $8(1.9 \%)$ & $19(7.9 \%)$ & $2(4.6 \%)$ & $13(11.1 \%)$ & $5(3.1 \%)$ & 0.006 \\
\hline Chlamidya trochomatis & $70(17 \%)$ & $47(19.7 \%)$ & $12(27.9 \%)$ & $8(6.8 \%)$ & $21(12.9 \%)$ & $<0.001$ \\
\hline Standart flora & $163(39.5 \%)$ & $102(42.7 \%)$ & $17(39.5 \%)$ & $44(37.6 \%)$ & $47(28.8 \%)$ & 0.17 \\
\hline \multicolumn{7}{|l|}{ Treatment Outcome } \\
\hline Hospitalization duration & $5.02 \pm 1.14$ & $3.87 \pm 1.01$ & $3.03 \pm 1.21$ & $4.07 \pm 1.83$ & $5.84 \pm 2.03$ & 0.29 \\
\hline Re-hospitalization & $109(26.5 \%)$ & $23(9.7 \%)$ & $19(44.2 \%)$ & $29(24.8 \%)$ & $47(28.8 \%)$ & 0.008 \\
\hline
\end{tabular}

There are some factors preventing the full understanding of the role of $\mathrm{Cu}$-IUD in the development of gynecological infections. Many genital infections are asymptomatic. One of the most important examples among these is C. Trochomatis. It is difficult under these conditions to determine whether PID, which develops secondary to this microbial agent, which can cause tubal infertility and chronic pelvic pain, due to the upper genital tract infection that causes tubal damage and adhesions (23), is caused by Cu-IUD (24). In addition, in another study, it was shown that $C$. Trochomatis positivity did not contribute to the development of PID in Cu-IUD users (24). Considering our study results, the most common contraceptive method used in patients with a history of PID was $\mathrm{Cu}$ IUD. This finding is not a surprise when compared with the data in previous studies, but the fact that $\mathrm{Cu}-\mathrm{IUD}$ is one of the contraceptive methods frequently used in our country may explain the high number of patients in the group. However, although $C$. Trochomatis was the most common bacterium grown in cervicovaginal culture in this study, there was no correlation with C. Trochomatis positivity in PID patients using $\mathrm{Cu}-\mathrm{IUD}$.

In a previous study examining microbial cultures in patients with PID, the most frequently grown bacteria were E. Coli (26.4\%) and other Enterococcus species (24\%) (25). In another study, S. Aureus was the most common bacteria (26). In another study conducted with a large patient population in Asia, bacteria that multiplied frequently in PID patients; E. coli, Proteus mirabilis, S. aureus, Group B Streptococcus and Klebsiella pneumoniae (27). In our study, the second most common bacterium that multiplied in cervicovaginal cultures was E. Coli after C. Trochomatis. It has been reported in various publications that oral hormonal contraceptive methods have positive effects on the vaginal microflora and reduce the risk of PID $(28,29)$.

Estrogen in the content of COC increases the amount of glycogen in vaginal epithelial cells and increases the growth of Lactobacillus bacteria and contributes to the reproduction of healthy vaginal microbial flora (3033). In a study conducted among women using COC as a contraceptive method and women using a barrier method, it was shown that Lactobacillus reproduce more in the vaginal microflora of COC users (31). In the data in our study, C. Trochomatis and Staphylococcus positivity were found in the cervicovaginal cultures of PID patients using COC. These changes can be explained depending on the effects of COC on flora.

Information on the effects of progesterone-containing contraceptive methods on the vaginal microflora is still contradictory. In a study examining the vaginal flora of patients using oral contraceptive drugs containing progesterone and using LNG-IUD; It has been determined that due to atrophy caused by progesterone, glycogen content in vaginal epithelial cells decreased and vaginal microflora was negatively affected (34). However, some studies have shown that the use of LNG-IUD has no effect on vaginal microflora $(35,36)$. In a study conducted with DMPA users, it was stated that there was a decrease in the prevalence of lactobacilli in the vaginal microflora, while another study reported that it had no effect on microflora $(37,38)$. In our study, positivity of E. Coli in cervicovaginal culture in PID patients using LNG-IUD, positivity of group B Streptococcus in condom users and C. Trochomatis positivity in DMPA users were frequent. These findings may be related to the negative effects of progesterone and barrier methods mentioned in publications on the vaginal microflora. 
In addition, considering the re-hospitalization rates of the patients, we found that this rate increased in DMPA users. This may be related to the persistent infection of $C$. Trochomatis, which is the most common agent in patients using DMPA.

This study has some limitations. Firstly our study is single-centered, and common contraceptive methods used among patients admitted to our center were investigated. Secondly, the study is a cross-sectional study. The data registered in the hospital database were analyzed retrospectively. In the light of these findings, the data should be considered before generalizing to the society.

\section{CONCLUSION}

In women presenting with acute PID clinic, contraceptive methods may have an impact on treatment selection and results. It should be kept in mind that contraceptive methods to be chosen in patients with a history of PID may affect the genital flora and may be a predisposing factor for the development of PID or prevent the development of PID.

\section{ETHICAL DECLARATIONS}

Ethics Committee Approval: Ethics committee approval was received for this study from the Adiyaman University Non-interventional Clinical Researches Ethics Committee (No: 2020/6-23).

Informed Consent: Because the study was designed retrospectively, no written informed consent form was obtained from patients.

Referee Evaluation Process: Externally peer-reviewed.

Conflict of Interest Statement: The authors have no conflicts of interest to declare.

Financial Disclosure: The authors declared that this study has received no financial support.

Author Contributions: All of the authors declare that they have all participated in the design, execution, and analysis of the paper, and that they have approved the final version.

\section{REFERENCES}

1. Workowski KA, Bolan GA. Sexually transmitted diseases treatment guidelines, 2015. MMWR. Recommendations and reports: Morbidity and mortality weekly report. Recommendations and Reports 2015; 64: 1-137.

2. Ford GW, Decker CF. Pelvic inflammatory disease. Disease-amonth: DM 2016; 62: 301.

3. Campbell S, Monga A. (Eds.). Gynaecology by ten teachers. London: Arnold. 2000, (pp. 41-54).

4. Kansagara D, Englander H, Salanitro A, et al. Risk prediction models for hospital readmission: a systematic review. JAMA 2011; 306: 1688-98.
5. Lee NC, Rubin GL, Grimes DA. Measures of sexual behavior and the risk of pelvic inflammatory disease. Obstet Gynecol 1991; 77: 425-30.

6. Kreisel K, Torrone E, Bernstein K, Hong J, Gorwitz R. Prevalence of pelvic inflammatory disease in sexually experienced women of reproductive age-United States, 2013-2014. MMWR Morb Mortal Wkly Rep 2017; 66: 80-3.

7. Trent M, Haggerty CL, Jennings JM, Lee S, Bass DC, Ness R. Adverse adolescent reproductive health outcomes after pelvic inflammatory disease. Arch Pediatr Adolesc Med 2011; 165: 4954.

8. Goyal M, Hersh A, Luan X, Localio R, Trent M, Zaoutis T. National trends in pelvic inflammatory disease among adolescents in the emergency department. J Adolesc Health 2013; 53: 249-52.

9. Matters JS, Catchpole M, Smith C. Chlamydia trachomatis: summary and conclusions of CMO's Expert Advisory Group. 1998. London: Department of Health.

10.Centers for Disease Control and Prevention 1998 Guidelines for the Treatment of Sexually Rransmitted Diseases, MMWR Morb Mortal Wkly Rep 1997; 47: 1- 111.

11.Jatlaoui TC, Riley HEM, Curtis KM. The safety of intrauterine devices among young women: a systematic review. Contraception 2017; 95: 17-39.

12.Stanwood NL, Garrett JM, Konrad TR. Obstetriciangynecologists and the intrauterine device: A survey of attitudes and practice. Obstet Gynecol 2002; 99: 275-80.

13. Madden T, Allsworth JE, Hladky KJ, Secura GM, Peipert JF. Intrauterine contraception in Saint Louis: A survey of obstetrician and gynecologists'knowledge and attitudes. Contraception 2010; 81: 112-6.

14. Fraser IS. Non-contraceptive health benefits of intrauterine hormonal systems. Contraception, 2010; 82: 396-403.

15. Schindler AE. Non-contraceptive benefits of oral hormonal contraceptives. Int J Endocrinol Metab 2013; 11: 41-7.

16. Havens JM, Olufajo OA, Cooper ZR, Haider AH, Shah AA, Salim A. Defining rates and risk factors for readmissions following emergency general surgery. JAMA Surg 2016; 151: 330-6.

17. Brunham RC, Gottlieb SL, Paavonen J. Pelvic inflammatory disease. N Engl J Med 2015; 372: 2039-48.

18. McGregor JA, French JI, Jones W, et al. Bacterial vaginosis is associated with prematurity and vaginal fluid mucinase and sialidase: results of a controlled trial of topical clindamycin cream. Am J Obstet Gynecol 1994; 170: 1048-59.

19. Draper DL, Landers DV, Krohn MA, Hillier SL, Wiesenfeld HC, Heine RP. Levels of vaginal secretory leukocyte protease inhibitor are decreased in women with lower reproductive tract infections. Am J Obstet Gynecol 2000; 183: 1243-8.

20. Hubacher D. Intrauterine devices and infection: review of the literature. Indian J Med Res 2014; 140: S53-7.

21.Liabsuetrakul T, Peeyananjarassri K. Mechanical dilatation of the cervix during elective caeserean section before the onset of labour for reducing postoperative morbidity. Cochrane Database Syst Rev 2018; 8: CD008019.

22.Sel G, Harma MI. Bacterial colonization of intrauterine device samples from patients without a history of pelvic inflammatory disease. Ann Med Res 2020; 27: 1036-9.

23. Witkin SS, Minis E, Athanasiou A, Leizer J, Linhares IM. Chlamydia trachomatis: the persistent pathogen. Clin Vaccine Immunol 2017; 24: e00203-17.

24.Birgisson NE, Zhao Q, Secura GM, Madden T, Peipert JF. Positive Testing for Neisseria gonorrhoeae and Chlamydia trachomatis and the risk of pelvic inflammatory disease in IUD users. J Womens Health (Larchmt) 2015; 24: 354-9. 
25.Lurie S, Asaala H, Harari OS, Golan A, Sadan O. Uterine cervical non-gonococcal and non-chlamydial bacterial flora and its antibiotic sensitivity in women with pelvic inflammatory disease: did it vary over 20 years? Isr Med Assoc J 2010; 12: 747-50.

26. Audu BM, Kudi AA. Microbial isolates and antibiogram from endocervical swabs of patients with pelvic inflammatory disease. J Obstet Gynaecol 2014; 24: 161-4.

27. Judlin P, Liao Q, Liu Z, Reimnitz P, Hampel B, Arvis P. Efficacy and safety of moxifloxacin in uncomplicated pelvic inflammatory disease: the MONALISA study. BJOG 2010; 117: 1475-84.

28. Schindler AE. Non-contraceptive benefits of hormonal contraceptives. Minerva Ginecol 2010; 62: 319-29.

29. Huber JC, Bentz EK, Ott J, Tempfer CB. Non-contraceptive benefits of oral contraceptives. Expert Opin Pharmacother 2008; 9: 2317-25.

30. Brooks PJ, Edwards DJ, Blithe DL, et al. Effects of combined oral contraceptives, depot medroxyprogesterone acetate, and the levonorgestrel releasing Intrauterine system on the vaginal microbiome. Contraception 2017; 95: 405-13.

31. Rifkin SB, Smith MR, Brotman RM, Gindi RM, Erbelding EJ. Hormonal contraception and risk of bacterial vaginosis diagnosis in an observational study of women attending STD clinics in Baltimore, MD. Contracept 2009; 80: 63-7.

32. O'Hanlon DE, Lanier BR, Moench TR, Cone RA. Cervicovaginal fluid and semen block the microbicidal activity of hydrogen peroxide produced by vaginal lactobacilli. BMC Infect Dis 2010; 10: 120 .

33. O'Hanlon DE, Moench TR, Cone RA. In vaginal fluid, bacteria associated with bacterial vaginosis can be suppressed with lactic acid but not hydrogen peroxide. BMC Infect Dis 2011; 11: 200.

34. Donders G, Bellen G, Janssens D, Van Bulck B, Hinoul P, Verguts J. Influence of contraceptive choice on vaginal bacterial and fungal microflora. Eur J Clin Microbiol Infect Dis 2017; 36: 43-8.

35. Jacobson JC, Turok DK, Dermish AI, Nygaard IE, Settles ML. Vaginal microbiome changes with levonorgestrel intrauterine system placement. Contraception 2014; 90: 130-5.

36. Hashway SA, Bergin IL, Bassis CM, et al. Impact of a hormonereleasing intrauterine system on the vaginal microbiome: a prospective baboon model. J Med Primatol 2014; 43: 89-99.

37. Borgdorff $\mathrm{H}$, Verwijs MC, Wit FWNM et al. The impact of hormonal contraception and pregnancy on sexually transmitted infections and on cervicovaginal microbiota in african sex workers. Sex Transm Dis 2015; 42: 143-52.

38. Mitchell CM, McLemore L, Westerberg K, et al. Long-term effect of depot medroxyprogesterone acetate on vaginal microbiota, epithelial thickness and HIV target cells. J Infect Dis 2014; 210: 651-5. 